\title{
Miracle in the Darkhouse (Zázrak v černém domě)
}

Author: Milan Uhde

First Published: 2012

Translations: English (Miracle in the Darkhouse, 2008); Croatian (Chudo v kuci jada, 2009); Russian (Čudo v černom dome, 2009); Spanish (Miracle a la casa negra, 2010); Bulgarian (Čudo v chernata kyshta, 2011); Hungarian (Csoda az elátkozott házban, 2017; Csoda a fekete házban, 2018).

Theatre Adaptations: Theatre Na Zábradlí, Prague (2007); Moravské divadlo, Olomouc (2008); Bohemian National Hall, New York (2008); Quatre per Quatre Teatre, Granollers, Barcelona (2011); Katona József Theatre, Budapest (2017); Národní divadlo - Reduta, Brno (2018); Západočeské divadlo, Cheb (2018).

About the Author: Milan Uhde (1936 in Brno) is a playwright, writer and politician from a Czech-Jewish assimilated family of lawyers. After graduating in Czech and Russian studies (1958), he became an editor for the prominent review for literature and art Host do domu. In the 1960s, he started his literary career writing three collections of stories and the satirical anti-regime play King Vâvra (premiered 1964), followed by the play The Bitch of Thebes (1967). After the Soviet occupation in August of 1968, during the so-called normalisation, he was forced to publish either in samizdat or under assumed names. He was one of the first signatories of Charter 77. Just after the Velvet Revolution he became editor-in-chief of the publishing house Atlantis as well as a lecturer at Janáček Academy of Performing Arts in Brno. In 1990 he was appointed to the position of Czech Minister of Culture; he also represented ODS (Civic Democratic Party) in the Czech National Parliament and, after the division of Czechoslovakia in 1993, he became the speaker of the House of Deputies of the Czech Parliament. In 1998 he decided to give up active politics and returned to writing and publishing. His earlier work was also republished by Atlantis.

Further Important Publications: Velice tiché Ave a jiné hry (samizdat 1986, Toronto 1988, Ave Maria Played Softly and Other Plays; six plays); Desítka her (1995, Ten Plays; plays); Balada pro banditu a jiné hry na zapřenou (2001, Ballad for a Bandit and Other Denied Plays; 11 theatre adaptations, played in 1970s and 1980s under assumed names).

\section{Content and Interpretation}

The play starts when Dušan Pompe, the elder son of the owners of the "Darkhouse", arrives with his wife Vitka for a family gathering in June of 1992. Dušan is coming to visit his despotic father Eduard, Jewish mother Heda, catatonic sister Šarka and

Ә Open Access. ( 2021 Agata Firlej, published by De Gruyter. (cc) BY-NC-ND This work is licensed under a Creative Commons Attribution-NonCommercial-NoDerivatives 4.0 License.

https://doi.org/10.1515/9783110671056-066 
brother Ivan who had cooperated with the Communist police. Relationships among family members are tenuous. Everyone starts to quarrel, old grievances and illusions come to the surface. In a mysterious way, the roots of the family's problems lead to the circumstances of building the Darkhouse. It was conceived as an impressive family residence by at the time young lady (mother), as a sign of her success and aspirations. It was also a way to put pressure on young Dr Eduard Pompe (father), who had avoided marriage for some years. He was afraid of his family's tendency to mental instability, but eventually, he offered to marry the Jewish lady lawyer. The Darkhouse - named this way because of its black elevation and simple functionalistic block - has left its mark on the whole family. Dr Pompe is attached to it so strongly, that he refused to take his Jewish wife and her parents abroad when the danger of World War II appeared. Later he also refused to sell the house, which would have enabled him to pay for his brother-in-law's flight to escape the Nazis. Dr Pompe's strategy was to falsify documents that could prove that his wife was in fact not her parents' daughter and did not have Jewish blood. Denying her Jewishness caused her long-lasting feelings of guilt. Later in the 1970s, his son Dušan became an anti-Communist dissident. Dr Pompe disinherited him being afraid the family would lose the Darkhouse. For the same reasons, the father tried to prevent his daughter Šárka from being committed to a psychiatric clinic. He was afraid, that if Šárka's husband divorced her, she couldn't keep their daughter and this would cause the granddaughter's share of the house would pass to a "foreign" family.

The microhistory of Pompe family in the 1990s is strongly connected with socalled macrohistory, major historical events. Within a family just as within a society ex-dissidents (Dušan) and ex-informers for the Communist regime (Ivan); tolerant women (mother) and despotic men (father Eduard Pompe) all meet with each other. And they all have some skeletons in their closets.

Like in absurd theatre, everybody talks but nobody listens and no one understands each other. The problems with communication seem to be the most important topic here and they are responsible for building the atmosphere of tension and intensifying frustration in the play.

\section{Main Topics and Problems}

Milan Uhde's play contains autobiographical threads which he has developed in an artistic and universalising form (for instance symbolic names: Pompe refers to "pomp”, Dušan is connected with „duše“, soul; Dušan calls his siblings Sarah and Joseph). Finding a root and a solution to the cursed heritage of the family memory is both painful and grotesque. The Darkhouse symbolises this aggravating heritage as well as the impossibility of getting rid of it.

Dušan: The question is whether we are Jews.

Ivan: Everyone thinks we are.

Dušan: What everyone thinks isn’t always right. Proof? Ma survived the entire war at home. 
Ivan: Because Dad stood by her. He didn’t divorce her. He acted like a man.

Mother: Change the subject, will you?

Ivan (to mother): Is it still taboo? Excuse me then.

Dušan: We are Jews after mother. Not after father. But there is one other version that says we're not Jews even after mother. There are documents.

Ivan: What kind? And when?

Dušan: Ask about them. Only watch out. I tried to. It's been almost two years to the day. He threw me out of the house.

Mother: Any other father would have half-killed you.

Dušan: And what did I say? That he sent his brother-in-law to the firing squad. Wasn't that right? It was. (Uhde, 2012, pp. 49-50; Tomáš, 2015, 222)

The very beginning - the circumstances of building the house - are connected with sin, bad intentions and such is the foundation of Pompe family.

The play shows sick relationships, problems and traumas in the family: the poisoning mixture of bourgeois morality, feeling guilty and the psychological traces left by Communist regime. The conserved illusions and injustices float to the surface, but the unbearable problems with communication make understanding and reconciliation impossible.

\section{Cited Works}

Tomáš, F. (2015). Family - an Unpredictable Joke. Milan Uhde’s Family Plays. In: R. Ibler, ed., Der Holocaust in den mitteleuropäischen Literaturen und Kulturen seit 1989. Stuttgart: ibidem-Verlag, pp. 215-223. Uhde, M. (2012). Zázrak v černém domě. Brno: Větrné mlýny.

\section{Further References}

Interview USC Shoah Foundation - Milan Uhde. (2000). ID 26943 (available at the Malach Centre of Visual History, Prague). Kočičková, K. (2007). Milan Uhde stvořil Zázrak $v$ černém domě (interview with M. Uhde), 08.12. Available at: https://www.idnes. cz/kultura/divadlo/milan-uhde-stvoril-zazrak-v-cernem-dome.A070309_203225_diva dlo_off [Accessed: 08.12.2019]. Mareček, L. (2018). Zázrak v černém domě. Když praskají vztahy i potrubí. Lidové noviny, (31), 20.05. Available at : https://www.lidovky. cz/kultura/recenze-zazrak-v-cernem-dome-kdyz-praskaji-vztahy-i-potrubi.A180511_11 0144_ln_kultura_jto [Accessed: 08.12.2019]. Mlejnek, J. (2007). Uhde se vrátil ve skvělé formě. Host, 23(3), p. B6. Mlejnek, J. (2018). Dělají-li dva totéž, není to totéž. Divadelní noviny, 27(12), p. 4. 